\title{
LET'S TALK ABOUT SEX: A ROLE FOR NURSES AND TEACHERS IN SECONDARY SCHOOLS
}

\author{
Madison Gartner
}

\section{INTRODUCTION}

Sexual and reproductive health is an essential component of healthy youth development. Sexuality education in secondary schools is an excellent opportunity for collaboration between nurses and teachers to provide a thorough and multi-faceted approach that best meets students' needs (Allen, 20II). Sexuality education is a mandatory part of the New Zealand Curriculum for Years I through Years 10 (Ministry of Education, 2019). The Ministry of Education (2015) published sexuality education guidelines to better meet the changing social environment and broader understandings of sexuality. Despite the development of these guidelines, the 2018 Education Review Office (ERO) report shows there are still large inconsistencies in teaching. Over half of New Zealand schools are not teaching sexuality education to a high standard, and the overall delivery of sexuality education has scarcely changed since the previous 2007 report. As sexuality education currently lacks quality and consistency, a priority in New Zealand Health and nursing should be to provide effective sexuality education for all youth (Education Review Office [ERO], 2018; Garland-Levett, 2017). School nurses and secondary school teachers play a critical role in providing sexuality education for youth. Therefore, assessing the two professions' ability to teach sexuality education effectively could establish a more effective strategy for sexuality education delivery (Allen, 20II; Ministry of Education, 2015). This paper will explore the effectiveness of nurses and secondary school teachers as sexuality educators, and how an improved collaborative approach could have a significant positive impact in delivering effective sexuality education.

\section{BACKGROUND}

Sexuality education curriculum coverage continues to be inconsistent across New Zealand. Biological aspects of sexuality and puberty are covered thoroughly, but aspects such as consent, digital technologies, gender and sexual diversities, sexual violence, and pornography need further depth of coverage $(E R O, 2018)$. The in-depth coverage of biological aspects of sexuality can be seen through the improvement of high-level indicators of sexual heath in youth, with the rate of sexually transmitted infections (STIs) decreasing between 2010 and 2014 (The Institute of Environmental Science and Research Ltd., 20I5), the rate of teenage pregnancies decreasing between $200 \mathrm{I}$ and 2013 (Statistics New Zealand, 2013), and the reduction of young women having abortions (Statistics New Zealand, 2017). These changes could also be attributed to other initiatives such as the introduction of Standing Orders for nurses to treat STIs in schools (Denny et al., 2014). While these improvements are encouraging, sexuality education needs to meet a much broader range of well-being outcomes than these statistics can provide, and with fewer inconsistencies across schools (ERO, 20I8).

Sexuality education in schools is usually the first opportunity to promote sexual and reproductive health. Therefore, optimising sexuality education for New Zealand secondary school students is important because it supports the healthy development of New Zealand youth who are our future (Ministry of Health, 2017). It is crucial that the 
educator who delivers sexuality education is knowledgeable in the subject and comfortable in delivering it. An effective sexuality educator that is knowledgeable and comfortable in their delivery is pertinent to successfully supporting youth to positively learn about and experience their sexuality (Allen, 2009). Currently the majority of New Zealand secondary school students are taught sexuality education by their regular teacher, however, the $\mathrm{ERO}(2018)$ report suggests that teachers are often uncomfortable teaching beyond biological aspects of sexuality and miss broader outcomes for sexual and reproductive health (ERO, 2018; Family Planning, 2019). School nurses can be an additional source of sexuality education through school-based clinics or periodic school visits. School nurses are present in the majority of New Zealand secondary schools and are viewed as professionals with good knowledge of sexual and reproductive health (Allen, 2009; ERO, 2018). Assessing the strengths and weaknesses of both nurses and teachers in delivering sexuality education could provide a foundation for an optimal collaborative approach in delivering sexuality education to secondary school students.

Assessing whether the delivery of sexuality education is effective can be challenging. A reduction of Sexually Transmitted Infections (STIs) and unplanned pregnancies in youth are thought to be the best indicators of effective sexuality education by many adults, however, Allen (2005) suggests that New Zealander's youth have differing views on what effective sexuality education looks like, for example more extensive discussion around safe use of technologies. This is likely because sexuality education is more extensive than the physical aspects of safe sex as it also covers emotional, social, and spiritual aspects. Therefore, it is important to consider what students conceptualise as effective for themselves (Allen, 2005). With consideration to these perspectives, a literature review was completed to examine how effective teachers and nurses are in the delivery of sexuality education to secondary school students. Despite sexuality education being a topical issue in New Zealand, there remains little evidence to address how nurses and teachers could collaborate to deliver it. The review of literature examined five qualitative studies that included school student discussions about how effective teachers and nurses were at teaching sexuality education, and one quantitative study that used a group-randomised intervention study to examine the differential impacts between nurse-led and teacher-led sex education. The literature indicates that secondary school students prioritise the independent qualities that the educator possesses over the type of sexuality educator, that is, a nurse or a teacher. Therefore, the strengths, limitations and independent qualities of teachers and nurses should be considered to better enhance sexuality education (Allen, 2009; Borawski et al., 2015).

\section{DISCUSSION}

Secondary students from both New Zealand and overseas report inconsistencies in teacher competency in teaching sexuality education. Where some teachers are especially effective, others struggle and limit discussions due to embarrassment and discomfort around the subject content (Allen, 2009; Lester \& Allan, 2006). Teachers who keep a narrow focus tend to teach strictly to the curriculum requirements leaving students feeling reluctant to express themselves freely and ask questions (Kimmel et al., 20I2). Furthermore, many students feel judged by some teachers and are concerned about their indiscretion, with particular anxiety around information being shared that may negatively impact other parts of their school life (Allen, 2009; Kimmel et al., 20I2). There is also an issue with teachers failing to control bigoted and homophobic comments made by other students, which creates an environment where students feel unable to participate safely. These fears of judgement and confidentiality lead to poor engagement from students in their sexuality education and thus reduces its effectiveness (Allen, 2005). Despite these criticisms, many secondary school students still prefer teachers as their sexuality educators (Allen, 2009). While some teachers find sexuality education challenging, others are exceptional when they are more comfortable with the subject content. Some students have reported finding their teacher more prepared, comfortable, and informative in comparison to other educators such as nurses. This is likely because teachers are well known to students and therefore have more opportunities to develop rapport and trust (Allen, 2009; Borawski et al., 2015). Students tend to favour their teacher as the ideal sexuality educator when they have a preexisting safe and comfortable relationship (Allen, 2009). 
Nurse-led sexuality education is far less common in secondary schools; however, many students have had interactions regarding their sexual and reproductive health with nurses in other contexts such as school nurse clinics, public health nurses, and practice nurses in the community. Despite limited experiences with nurses as sexuality educators, several secondary school students believe nurses are the ideal sexuality educators (Allen, 2009). Secondary school students generally perceive nurses as more credible sources of information who possess greater medical knowledge relating to sexual and reproductive health. The nurse's scope of knowledge and practical experience is incredibly valuable, especially when facilitating open discussions and answering questions (Allen, 2009; Kimmel et al., 2012). Qualities such as being authoritative, knowledgeable, and comfortable with sexuality education were more often attributed to nurses than teachers (Allen, 2005). Moreover, many secondary school students believe nurses are more approachable and confidential, and less judgmental on the topic of sexuality than teachers generally are (Kimmel et al., 2012). A nurse's anonymity as an educator can be very favourable to students who may feel embarrassed sharing information and engaging in activities with someone they see regularly (Allen, 2009; O'Higgins \& Gabhainn, 2010). Secondary school students also find individualised nursing services outside of sexuality education favourable as they are able to extend their knowledge in a more confidential setting (Kimmel et al., 2012). Care should be taken by nurses not to make inaccurate assumptions about students' sexual behaviour as these assumptions can make them feel alienated and result in disengagement from learning (Kimmel et al., 2012).

Understanding what secondary school students perceive makes an effective sexuality educator is fundamental if educators wish to best address the students' needs and interests (Allen, 2009). Secondary school students generally share similar views on what educator qualities are effective in teaching sexuality education. Being knowledgeable, professional, and specialist are the most popular qualities students favour in a sexuality educator. Relatability, openness, and the ability to speak candidly about sexual issues are also greatly valued (Allen, 2005; Allen, 2009). While more students associate nurses with these ideal qualities, some students associate teachers with them instead. Students attribute the same positive qualities to all educators, indicating that ideal characteristics are not perceived as belonging specifically to an educator type. This implies that the relationship between the educator type and the best educator qualities may be more random (Allen, 2009).

Evidence shows that both teachers and nurses can be effective in significantly improving secondary school student's knowledge of HIV, STIs, and condoms. However, secondary school students taught sexuality education by nurses tend to report more significant and prolonged changes compared to those taught by teachers (Borawski et al., 2015). Secondary school students taught by nurses show greater sustained positive changes in attitudes, beliefs, and self-efficacy than those taught by teachers (Borawski et al., 2015). Nurses' ability to build self-efficacy and self-competence in individuals is a valuable characteristic for an educator as effective sexuality education requires youth to learn behaviours that will protect their sexual and reproductive health long-term (Borawski et al., 20I5).

A collaborative approach would be ideal so that the strengths of both nurses and teachers can be utilised to optimise sexuality education for secondary school students. While classroom teachers are able to convey knowledge well, they could do with support in achieving better long-term sexual health results for their students. Comparatively, nurses are particularly useful in assisting students to build life-long skills and reduce risky sexual behaviours (Borawski et al., 2015). A teacher is more suitable to provide a known and comfortable environment for students who prefer a sexuality educator that they have an established rapport with. Meanwhile, nurses are able to provide anonymity for those students who prefer an unknown educator and for those who may feel judged and unsafe elsewhere (Allen, 2009; Borawski et al., 2015). Qualities and characteristics will always vary between individuals; therefore it is important for secondary school teachers and school nurses to work together to coordinate an effective collaborative approach. 


\section{RECOMMENDATIONS}

Involving school nurses in classroom sexuality education is the ideal recommendation, however, it is not realistic for most schools to implement effectively. This is because school nurses already have busy workloads and are unlikely to be able to commit additional time outside of their normal practice to partake in classroom sexuality education. Fiscal constraints are another issue, as introducing non-teacher educators is likely to be unsustainable. These concerns have been taken into account in order to make realistic and effective recommendations (Borawski et al., 2015; Edmond, 2018).

\section{Build teacher capability}

The first recommendation is to build teacher capability through on-going professional development (Borawski et al., 2015; Edmond, 2018). Sexuality education should be taught be teachers who are committed, well-trained and participate regularly with health education professional development (ERO, 20I8; Family Planning, 2019). Up-todate professional development and training should be accessible to all teachers in order to successfully improve their confidence and capability in delivering effective sexuality education. This will involve ensuring that teachers have excellent basic knowledge of sex, sexuality and reproductive issues, are confident in their skills and ability to teach the topic, understand their role in promoting sexual health, and know the current and relevant information on local services and how students can access them (ERO, 20I8; Thistle \& Ray, 2002).

\section{Make use of sexuality education guidelines}

The second recommendation is for teachers to be guided by Sexuality Education: A guide for Principals, Boards of Trustees and Teachers (Ministry of Education, 2015) to ensure quality sexuality education is provided. This guide covers a broader range of issues that address the changing needs of youth such as, sexual health, reproduction, relationships, identity, gender and sexual diversity, consent, internet safety, and pornography. Quality sexuality education should build on two core aspects, identity and relationships (Family Planning, 20 I9; Ministry of Education, 2015). Further teaching and education sessions need to be held at schools to improve teacher understanding. To ensure guidelines are being used appropriately, ongoing evaluation of teachers' performance in sexuality education needs to occur.

\section{Use a collaborative approach between teachers and nurses}

The third recommendation is to optimise a collaborative approach between teachers and nurses in providing sexuality education to secondary school students. Implementing this recommendation could involve a nurse-led classroom session as well as encouragement of one-on-one discussions with a nurse such as through a school clinic (Borawski et al., 2015; Kimmel et al., 2012). School nursing clinics are already available in many secondary schools, however many students are still missing out. Therefore, nurse clinics need to be available in as many schools as possible (Buckley et al., 2009). Teachers need to be aware of their nurse clinics so that they can promote and direct their students to seek assistance when appropriate. An emphasis should be placed on the anonymity of school nurse clinics to encourage those who prefer a more private setting (Allen, 2009; Borawski et al., 2015). Secondary school teachers and school nurses need to establish a good relationship to coordinate an effective collaborative approach that best addresses the wide range of student needs and preferences.

\section{CONCLUSION}

The inconsistencies of sexuality education throughout New Zealand secondary schools is an issue that persists despite continuous attempts to make change (ERO, 20I8; Ministry of Education, 2015). Most sexuality education takes place in the classroom; therefore, this teaching time should be optimised. Secondary school teachers have a key role as sexuality educators, yet many teachers are unable to provide students with the quality sexuality 
education they require. There is a clear need for continuous professional development to improve teacher's capability and build positive characteristics for teaching sexuality education (Allen, 2005; Kimmel et al., 2012). Furthermore, secondary school teachers would benefit from reinforcement of the new sexuality education guidelines from the Ministry of Education (2015). Nurses also play an important role in sexuality education, often through nurse-led clinics. The unique skill set of nurses is particularly useful in building self-efficacy in students to produce more sustained changes that improve students sexual and reproductive health (Borawski et al., 20I5). The strengths and limitations of teachers and nurses should be considered on an individualised basis to develop an effective collaborative approach to sexuality education in secondary schools.

\section{ACKNOWLEDGMENTS}

I would like to thank Tyla Gartner for her thoughtful and detailed feedback in proofreading this paper.

Madison Gartner is a third-year Bachelor of Nursing student at Otago Polytechnic. She enjoys the range of opportunities nursing provides and the connection with the community it allows. Madison hopes to work as a Practice Nurse in the future and has a passion for sexual health and women's health.

Correspondence to: Madison Gartner, School of Nursing, Otago Polytechnic | Te Kura Matatini ki Otago, Forth Street, Private Bag 1910, Dunedin 9054, New Zealand. Email: mgartner@hotmail.com

\section{REFERENCES}

Allen, L. (2005). 'Say everything': exploring young people's suggestions for improving sexuality education. Sex Education, 5(4), 389-404. https://doi.org//0.1080//4681810500278493

Allen, L. (2009). 'It's not who they are it's what they are like': Re-conceptualising sexuality education's 'best educator' debate. Sex Education, 9(I), 33-49. https://doi.org/I0.1080/1468I8I08026398/4

Allen, L. (20II). Young people and sexuality education: Rethinking key debates. London, UK: Palgrave Macmillan.

Borawski, E. A., Tufts, K. A., Trapl, E. S., Hayman, L. L., Yoder, L. D., \& Lovegreen, L. D. (20I5). Effectiveness of health education teachers and school nurses teaching sexually transmitted infections/human immunodeficiency virus prevention knowledge and skills in high school. Journal of School Health, 85(3), 189-196. https://doi.org/l0.1 I II/josh. 12234

Buckley, S., McDonald, J., Mason, D., Gerring, Z., Churchward, M., \& Cumming, J. (2009). Nursing services in New Zealand secondary schools [PDF file]. Wellington: Health Services Research Centre, Victoria University of Wellington. Retrieved from https://www.wgtn.ac.nz/health/centres/health-services-research-centre/docs/reports/downloads/Nursing-Servicesin-Schools-Edited-19-Feb.pdf

Denny, S., Grant, S., Galbreath, R., Clark, T.C., Fleming, T., Bullen, P., Dyson, B., ... Teevale, T. (20l4). Health services in New Zealand secondary schools and the associated health outcomes for students. Auckland, New Zealand: University of Auckland.

Edmond, J. (2018, September 12). Why do we keep getting sexuality education in schools so wrong? Stuff. Retrieved from https:// www.stuff.co.nz/national/education/l0703141I/why-do-we-keep-getting-sexuality-education-in-schools-so-wrong

Education Review Office. (2018). Promoting wellbeing through sexuality education [PDF file]. Retrieved from https://www.ero.govt. nz/assets/Uploads/Promoting-wellbeing-through-sexuality-education.pdf

Family Planning. (2019). Young people's experiences of sexuality education [PDF file]. Retrieved from https://www.familyplanning. org.nz/media/303993/youth-survey-summary-report_march2019_final.pdf

Garland-Levett, S. (2017). Exploring discursive barriers to sexual health and social justice in the New Zealand sexuality education curriculum. Sex Education, 17(2), 121-134. https://doi.org/l0.1080/14681811.2016.1233396 
Kimmel, A., Williams, T. T., Veinot, T. C., Campbell, B., Campbell, T. R., Valacak, M., \& Kruger, D. J. (20I2). 'I make sure I am safe and I make sure I have myself in every way possible': African-American youth perspectives on sexuality education. Sex Education, 13(2), 172-185. https://doi.org/10.1080/1468/811.2012.709840

Lester, C., \& Allan, A. (2006). Teenage sexual health needs: asking the consumers. Health Education, 106(4), 315-328. https://doi. org/l0.1108/09654280610673490

Ministry of Education. (2015). Sexuality education: A guide for principals, boards of trustees, and teachers [PDF file]. Retrieved from https://health.tki.org.nz/content/download/28I7/2600I/version/3/file/Sexuality\%2BEducation\%2BGuide_27\%2BJuly\% 2B2016.pdf

Ministry of Education. (2019). Sexuality education. Retrieved from https://parents.education.govt.nz/primary-school/learning-atschool/sexuality-education/

Ministry of Health. (2017). Health and independence report 2017 [PDF file]. Retrieved from https://www.health.govt.nz/system/ files/documents/publications/health-and-independence-report-2017-v2.pdf

O'Higgins, S., \& Gabhainn, S. N. (2010). Youth participation in setting the agenda: learning outcomes for sex education in Ireland. Sex Education, 10(4), 387-403. https://doi.org/10.1080/14681811.2010.515096

Statistics New Zealand. (2013). Births Tables. Retrieved from http://archive.stats.govt.nz/browse_for_stats/population/births/birthstables.aspx

Statistics New Zealand. (2017). Abortion statistics: Year ended December 2016. Retrieved from http://archive.stats.govt.nz/browse_ for_stats/health/abortion/AbortionStatistics_HOTPYeDecl6.aspx

The Institute of Environmental Science and Research Ltd. (20I5). Sexually transmitted infections in New Zealand: Annual Surveillance Report 2014 [PDF file]. https://surv.esr.cri.nz/PDF_surveillance/STISurvRpt/20I4/FINAL20I4AnnualSTIReport.pdf

Thistle, S., \& Ray, C. (2002). Sex and relationships education: the role of the nurse [PDF file]. Nursing Standard, 17(I), 44-53. Retrieved from http://pdfs.semanticscholar.org//4ce/5208b227aae37fd4c8b0 I Id5637d482bd7d6.pdf 